\title{
Immunomodulatory activity of Tityus serrulatus scorpion venom on human $\mathrm{T}$ lymphocytes
}

Andrea Casella-Martins ${ }^{1}$, Lorena R Ayres ${ }^{1,2}$, Sandra M Burin ${ }^{1}$, Fabiana R Morais ${ }^{1}$, Juliana C Pereira' ${ }^{1}$ Lucia H Faccioli ${ }^{1}$, Suely V Sampaio ${ }^{1}$, Eliane C Arantes $^{3}$, Fabiola A Castro ${ }^{1}$ and Luciana S Pereira-Crott ${ }^{1 *}$

\begin{abstract}
Background: Tityus serrulatus scorpion venom (TsV) contains toxins that act on $\mathrm{K}^{+}$and $\mathrm{Na}^{+}$channels and account for the venom's toxic effects. TsV can activate murine peritoneal macrophages, but its effects on human lymphocytes have been poorly investigated. Considering that lymphocytes may play an important role in envenomation, we assessed whether TsV affects the expression of phenotypic (CD3, CD4, and CD8) and activation (CD69, CD25, and HLA-DR) markers, cell proliferation, and cytokine production in peripheral blood mononuclear cells.

Methods: Cytotoxicity of Ts V was evaluated via the MTT assay. Cell proliferation, expression of phenotypic and activation markers, and release of cytokines were assessed using flow cytometry, after treatment with non-cytotoxic concentrations of TsV. The combined use of carboxyfluorescein diacetate succinimidyl ester and monoclonal antibodies against phenotypic and activation markers enabled us to simultaneously assess cell proliferation extent and cell activation status, and to discriminate among cell subpopulations.

Results: Ts $V$ at concentrations of 25 to $100 \mu \mathrm{g} / \mathrm{mL}$ were not cytotoxic towards peripheral blood mononuclear cells. TsV did not induce significant changes in lymphocyte subpopulations or in the expression of activation markers on $\mathrm{CD}^{+}$and $\mathrm{CD}^{+} \mathrm{T}$ cells. TsV inhibited the phytohemagglutinin-stimulated lymphocyte proliferation, particularly in the $\mathrm{CD}^{+} \mathrm{CD}^{2} 5^{+} \mathrm{T}$ lymphocyte subset. TsV alone, at 50 and $100 \mu \mathrm{g} / \mathrm{mL}$, did not induce peripheral blood mononuclear cell proliferation, but elicited the production and release of IL-6, a proinflammatory cytokine that plays an important role in innate and adaptive immune responses.
\end{abstract}

Conclusions: TsV is a potential source of molecules with immunomodulatory action on human T lymphocytes.

Keywords: Immunomodulation, Immunophenotyping, T lymphocyte, Cell proliferation, Cytokine, Tityus serrulatus venom

\section{Background}

Scorpions from the family Buthidae are responsible for the majority of worldwide envenomations, especially in South Asia, the Middle East, Central and South America, and North Africa [1,2]. Tityus is one genus of this family, of which Tityus serrulatus is the most dangerous species -

\footnotetext{
*Correspondence: lupcrott@usp.br

'Department of Clinical Analyses, Toxicology and Food Sciences, School of Pharmaceutical Sciences of Ribeirão Preto, University of São Paulo (USP),

Avenida do Café, s/n, Ribeirão Preto, SP CEP 14040-903, Brazil

Full list of author information is available at the end of the article
}

it causes serious envenomation that may provoke fatalities, the majority of the victims are children [3-7].

Scorpion venom is composed of numerous toxins, mostly of peptides and neurotoxins, which act by deregulating cell membrane ion channels. Such toxins may cause pain, deregulation of cardiovascular and autonomic nervous systems, vomiting, abdominal pain, stimulation of peripheral nervous system, neuromuscular excitation, among other deleterious effects in humans [8].

Massive activation of the immune system seems also to participate in the pathogenesis of T. serrulatus envenomation. The plasma levels of NO and cytokines - such as 
interleukin-1 (IL-1), IL-6, IL-8 and interferon- $\gamma$ (IFN- $\gamma$ ) produced by immune cells - are increased in patients presenting moderate or severe T. serrulatus envenomation, and correlate with the severity of envenomation [9]. The participation of proinflammatory cytokines in the moderate and severe envenomation pathophysiology indicates that these patients may benefit from treatment with glucocorticoids.

Recent studies reported that the venom of $T$. serrulatus and its toxins activate murine macrophages, which are critical cells for the immune response because they participate in humoral and cellular responses [10-15]. However, the effect of Tityus serrulatus scorpion venom (TsV) on human lymphocytes remains to be investigated. Considering that $\mathrm{TsV}$ contains several toxins that act on membrane $\mathrm{K}^{+}$channels, and that these channels are involved in the regulation of cellular functions, in the present study we examined whether TsV interferes in peripheral blood mononuclear cell (PBMC) cytokine production, as well as in $\mathrm{T}$ lymphocyte phenotype, proliferation, and expression of activation markers.

\section{Methods}

\section{Source and preparation of venom}

$\mathrm{Ts} \mathrm{V}$ was obtained from the serpentarium of the Ribeirão Preto Medical School, University of São Paulo, Brazil, by using the electrical stimulation method with the minimal voltage required $(-12 \mathrm{~V})$ [16].

Lyophilized TsV $(4 \mathrm{mg})$ was diluted with $10 \mathrm{~mL}$ of sterile distilled water and fractionated by centrifugation $\left(10,015 \times \mathrm{g}, 4{ }^{\circ} \mathrm{C}, 10 \mathrm{~min}\right)$, yielding an insoluble and non-toxic fraction composed of mucoproteins and membrane debris. The soluble part was rich in basic neurotoxic proteins, but also contained various enzymes and organic (lipids, carbohydrates, nucleosides, free amino acids) and inorganic (ions) compounds. Protein concentrations in crude soluble venom were determined by absorbance readings at $280 \mathrm{~nm}$ using a NanoDrop 2000 spectrophotometer (Thermo Scientific, Wilmington, DE, USA) and the extinction coefficient of the soluble venom [17]:

$$
\varepsilon_{280 \mathrm{~nm}}^{1 \mathrm{mg} / \mathrm{mL}}=1.65
$$

\section{Peripheral blood mononuclear cell (PBMC) isolation and culture}

PBMC were isolated from venous blood of 20 healthy adult volunteers ( 7 males and 13 females, $20-40$ years old) via the Ficoll-Hypaque (Hystopaque ${ }^{-1077}$; SigmaAldrich, USA) discontinuous density centrifugation method. PBMC were washed twice, suspended in RPMI 1640 medium (GIBCO ${ }^{\circ}$, USA) to a concentration of $5 \times 10^{6}$ cells $/ \mathrm{mL}$. Cells were cultured in RPMI with phytohemagglutinin (PHA; $2 \mu \mathrm{g} / \mathrm{mL}$; SigmaAldrich, USA) and/or $\operatorname{TsV}(25,50$, and $100 \mu \mathrm{g} / \mathrm{mL})$ at $37{ }^{\circ} \mathrm{C}$ and under $5 \% \mathrm{CO}_{2}$, during the proliferation assay $(96 \mathrm{~h})$ and before the immunophenotyping assay $(24$ h). The Human Research Ethics Committee at FCFRP-USP approved the research protocol, registered under number CEP/FCFRP 166.

\section{Cytotoxicity evaluation}

The cytotoxic activity of $\mathrm{TsV}$ was evaluated using the MTT method described by Mosmann [18]. PBMC $\left(5 \times 10^{5}\right.$ cells/well $)$ were cultured in 96-well plates in RPMI 1640 complete culture medium containing $10 \%$ fetal calf serum (FCS) in the presence of $\mathrm{TsV}$ $(12.5 ; 25.0 ; \quad 50.0 ; \quad 62.5 ; 100.0 ; 125.0 ; 250.0 ; 500.0$; $1000.0 ; 2000.0 \mu \mathrm{g} / \mathrm{mL}$ ) or cyclophosphamide (Cyclo; $25 \mathrm{mg} / \mathrm{mL}$; positive control; Sigma-Aldrich, USA) previously diluted in culture medium, for $24 \mathrm{~h}$ at $37^{\circ} \mathrm{C}$, and under $5 \% \mathrm{CO}_{2}$. Next, $20 \mu \mathrm{L}$ of MTT (Sigma-Aldrich, USA) solution at $5 \mathrm{mg} / \mathrm{mL}$ was added to each well, and the plates were incubated for $4 \mathrm{~h}$, at $37^{\circ} \mathrm{C}$, and under $5 \%$ $\mathrm{CO}_{2}$. After incubation, the precipitated formazan crystals were dissolved with $200 \mu \mathrm{L}$ of $20 \%$ SDS (sodium dodecylsulfate), and absorbance was recorded at $570 \mathrm{~nm}$. Absorbance values recorded for untreated cells (negative control) represent $100 \%$ of PBMC viability, and were used as reference to calculate the percentage of cell viability in the presence of each sample concentration.

\section{Immunophenotyping of lymphocyte subsets and activation markers}

Flow cytometry analysis was performed to identify and quantify lymphocyte subpopulations (CD3-FITC, CD4-PE, and CD8-PE monoclonal antibodies), and to measure the levels of cellular activation markers expression (CD69, CD25, and HLA-DR monoclonal antibodies conjugated with APC) (Becton-Dickinson, USA).

PBMC $\left(2 \times 10^{5}\right.$ cells per well) were cultured with $\mathrm{TsV}$ $(25 ; 50 ; 100 \mu \mathrm{g} / \mathrm{mL})$ for $24 \mathrm{~h}$ at $37{ }^{\circ} \mathrm{C}$, and under $5 \%$ $\mathrm{CO}_{2}$. Cells were collected, suspended to a concentration of $1 \times 10^{6}$ cells in $100 \mu \mathrm{L}$ of FACS buffer (phosphate buffered saline - PBS, with $10 \%$ FCS and $1 \%$ sodium azide), and incubated with $1 \mu \mathrm{L}$ of monoclonal antibodies at the following concentrations $(\mathrm{mg} / \mathrm{mL})$ : 0.0031(CD4); 0.0125 (CD8); 0.012 (CD25); 0.2 (CD69); 0.05 (HLA-DR); and 0.1 (CD3), for $30 \mathrm{~min}$ at $4{ }^{\circ} \mathrm{C}$, in the dark. Then, the cells were washed with PBS and suspended in $100 \mu \mathrm{L}$ of PBS-FCS.

A total of 30,000 events per tube was acquired on the flow cytometer (FACSCanto, Becton-Dickinson, USA), the lymphocyte gate was selected according to its forward and side scatter distribution, and further analyzed with the aid of the software FACSDiva (Becton-Dickinson, USA). The results were expressed as percentages of 
stained cells. Additional file 1 depicts representative forward/side scatter dot-plots of human PBMC treated with $\mathrm{TsV}$.

\section{Cell proliferation assay}

The use of carboxyfluorescein diacetate succinimidyl ester (CFSE) in combination with monoclonal antibodies against phenotypic and activation markers enabled the concomitant determination of cell proliferation and activation status and discrimination of cell subpopulations.

PBMC were centrifuged, suspended to the concentration of $5 \times 10^{6}$ cells $/ \mathrm{mL}$ in PBS containing $0.1 \%$ human albumin, and labeled with CFSE $(2.5 \mu \mathrm{M}$; Molecular Probes, USA) for ten minutes at $37{ }^{\circ} \mathrm{C}$. The labeling process was stopped by addition of five volumes of icecold RPMI 1640 containing 10 \% FCS (RPMI-FCS) followed by incubation for five minutes in an ice bath, in the dark. The cells were washed three times with $20 \mathrm{~mL}$ of RPMI-FCS, and further suspended in the same medium.

PBMC were plated in 96-well plates $\left(5 \times 10^{5}\right.$ cells/well $)$ and cultured with PHA $(2 \mu \mathrm{g} / \mathrm{mL})$ and/or $\mathrm{TsV}(25,50$, or $100 \mu \mathrm{g} / \mathrm{mL}$ ) for $96 \mathrm{~h}$ at $37{ }^{\circ} \mathrm{C}$, and under $5 \% \mathrm{CO}_{2}$. The cells $\left(1 \times 10^{6}\right)$ were transferred to flow cytometry tubes and labeled with $2 \mu \mathrm{L}$ of the following monoclonal antibodies: anti-CD3/PerCP (Peridinin-chlorophyll-protein complex); anti-CD8, or anti-CD4 PE; anti-CD25, antiHLA-DR, or anti-CD69 APC (Becton-Dickinson, USA). A total of 30,000 events per tube was acquired on the flow cytometer (FACSCanto, Becton-Dickinson, USA) and analyzed with the aid of the software FACSDiva (Becton-Dickinson, USA). The lymphocyte gate was set on light-scatter properties (forward scatter vs. side scatter). The results were expressed as percentages of stained cells.

\section{Cytokine quantification}

The levels of tumor necrosis factor- $\alpha$ (TNF- $\alpha$ ), IL-2, IL-4, IL-6, IL-10, IL-17, and IFN- $\gamma$ in culture supernatants of PBMC $\left(1.0 \times 10^{5}\right.$ cells $)$ treated with PHA $(2 \mu \mathrm{g} / \mathrm{mL})$ and/ or $\operatorname{TsV}(25,50$, and $100 \mu \mathrm{g} / \mathrm{mL})$ for $96 \mathrm{~h}$ were quantified by flow cytometry, using the assay kit Cytometric Bead Array (CBA) Human Th1/Th2/Th17 Cytokine (BD Biosciences, USA) according to the manufacturer's instructions. The samples were analyzed on a FACSCanto cytometer with the aid of the CBA analysis software FCAP Array (version 1.01; BectonDickinson, USA). The cytokine concentration was expressed as $\mathrm{pg} / \mathrm{mL}$.

\section{Statistical analysis}

The results were expressed as mean \pm standard error of the mean (SEM). Statistical analysis was performed by one-way analysis of variance (ANOVA) followed by the
Tukey's test, using the software Graph Pad Prism 5. Significance was defined as $p<0.05$.

\section{Results}

TsV at lower concentrations is not cytotoxic towards PBMC

We used the MTT assay to examine whether TsV is cytotoxic towards PBMC. Compared with untreated cells, TsV at concentrations of 500,1000 , and $2000 \mu \mathrm{g} / \mathrm{mL}$ reduced cell viability by $12.7,22.2$, and $23.7 \%$, respectively. TsV was not cytotoxic towards PBMC at concentrations lower than $250 \mu \mathrm{g} / \mathrm{mL}$ (Fig. 1). Based on these results, we selected the TsV concentrations of 25, 50, and $100 \mu \mathrm{g} / \mathrm{mL}$ for further experiments.

TsV does not induce changes in T lymphocyte subpopulations and in the expression of PBMC activation markers

After $24 \mathrm{~h}$ of culture, TsV at concentrations of 25, 50, and $100 \mu \mathrm{g} / \mathrm{mL}$ did not induce significant changes in $\mathrm{TCD}^{+} \mathrm{CD}^{+}$and $\mathrm{CD}^{+} \mathrm{CD}^{+}$lymphocyte subpopulations, and did not modulate the expression of three activation markers - CD69, CD25 and HLA-DR - in PBMC (Fig. 2).

\section{TsV inhibits the proliferation of $\mathrm{CD} 8^{+} \mathrm{CD} 25^{+} \mathrm{T}$} lymphocytes

In PBMC previously stimulated with PHA, the 96-h treatment with $\mathrm{TsV}$ at 25,50 or $100 \mu \mathrm{g} / \mathrm{mL}$ reduced the

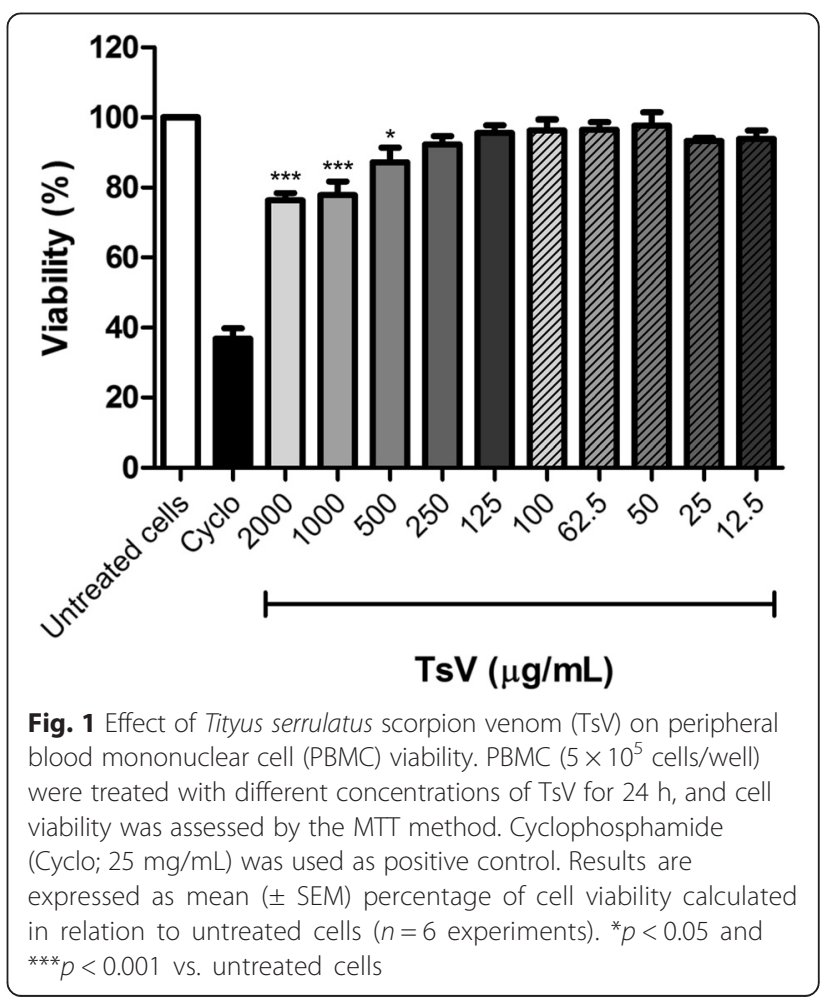



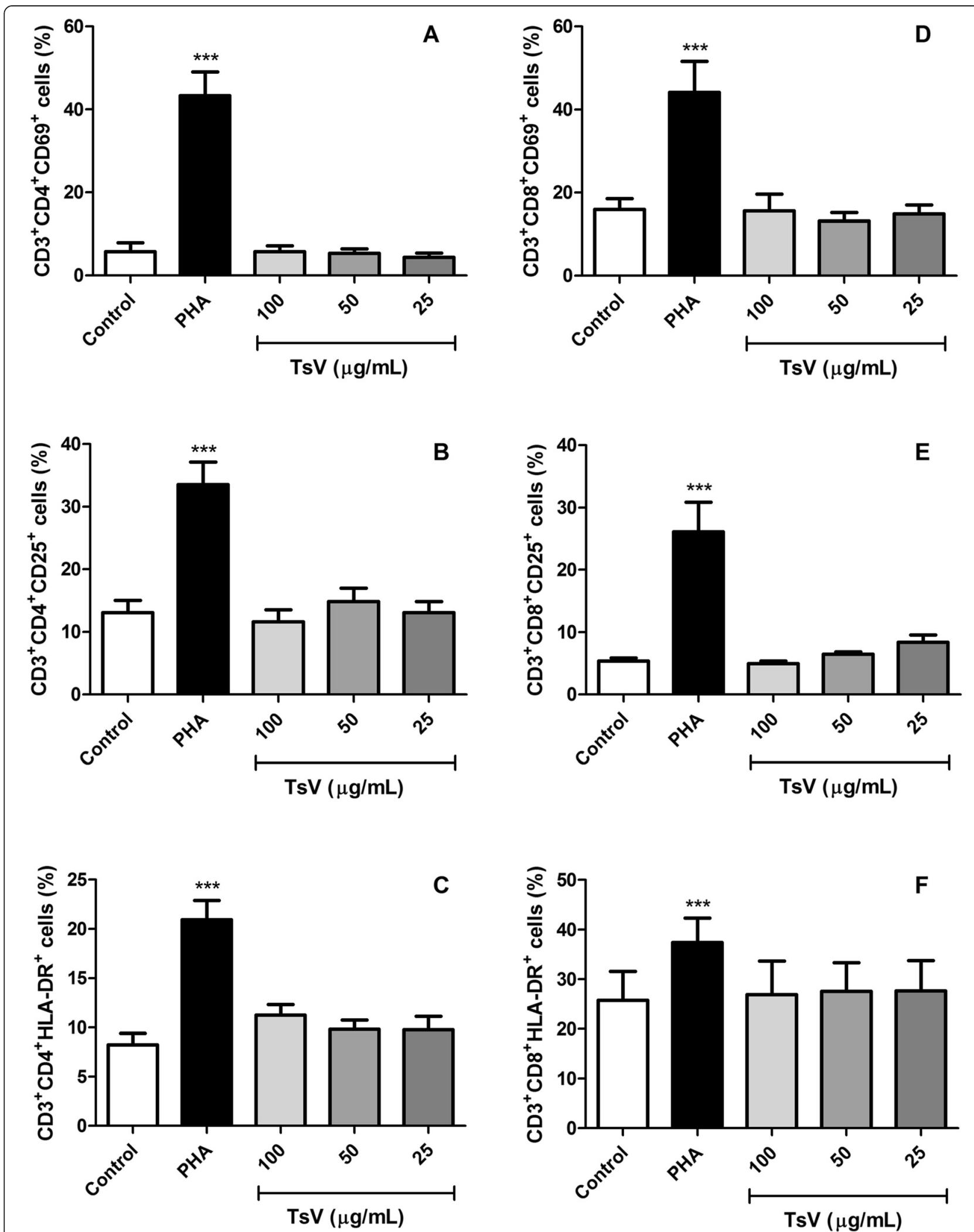

Fig. 2 (See legend on next page.)

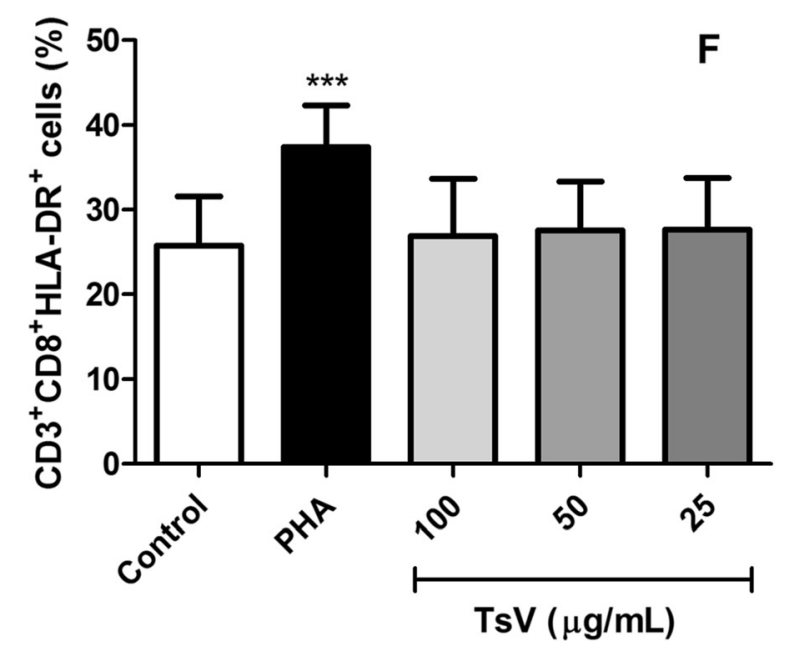


(See figure on previous page.)

Fig. 2 Lymphocyte subsets and their expression levels of activation markers after TsV treatment. Peripheral blood mononuclear cells ( $2 \times 10^{5}$ cells) were cultured with Tityus serrulatus scorpion venom (TsV; 25,50 , and $100 \mu \mathrm{g} / \mathrm{mL}$ ) or phytohemagglutinin (PHA; $2 \mu \mathrm{g} / \mathrm{mL} ; \mathrm{positive} \mathrm{control)} \mathrm{for}$ $24 \mathrm{~h}$, at $37^{\circ} \mathrm{C}$, under $5 \% \mathrm{CO}_{2}$, and further stained with monoclonal antibodies to simultaneously detect CD3 ${ }^{+} \mathrm{CD} 4^{+}(\mathbf{a}, \mathbf{b}, \mathbf{c})$ and $\mathrm{CD} 3^{+} \mathrm{CD} 8^{+}$ (d, e, f) T lymphocyte subsets, and the expression of three activation markers: CD69 (a, d), CD25 (b, e), and HLA-DR (c, f). Control: untreated cells. Data are expressed as mean \pm SEM of six experiments. ${ }^{* *} p<0.001$ vs. control

percentage of $\mathrm{CD}^{+} \mathrm{CD} 25^{+}$lymphocytes by 35.7, 45.5, and $53.5 \%$, respectively, i.e. in a concentrationdependent manner (Fig. 3). These values were statistically different from the respective control (PHA) at TsV concentrations of 50 and $100 \mu \mathrm{g} / \mathrm{mL}$ (Fig. 3). In contrast, $\mathrm{TsV}$ did not alter either $\mathrm{T}$ lymphocyte proliferation extent or the percentage of $\mathrm{CD}^{+} \mathrm{CD}_{4}^{+}$and $\mathrm{CD}^{+} \mathrm{CD} 4$ ${ }^{+} \mathrm{HLA}_{-} \mathrm{DR}^{+}$lymphocyte subsets in non-stimulated PBMC, as compared with PHA- and PHA + TsV-stimulated PBMC (data not shown).

\section{TsV induces IL- 6 release by PBMC}

TsV induced IL- 6 release by PBMC in a concentrationdependent manner. The IL-6 levels in culture supernatants of non-stimulated PBMC were significantly increased at $\mathrm{TsV}$ concentrations of 50 and $100 \mu \mathrm{g} / \mathrm{mL}$ $(p<0.05$ and $p<0.01$, respectively), compared with the respective control (CFSE) (Fig. 4). TsV did not alter IL-6 release in PHA-stimulated cells, or the

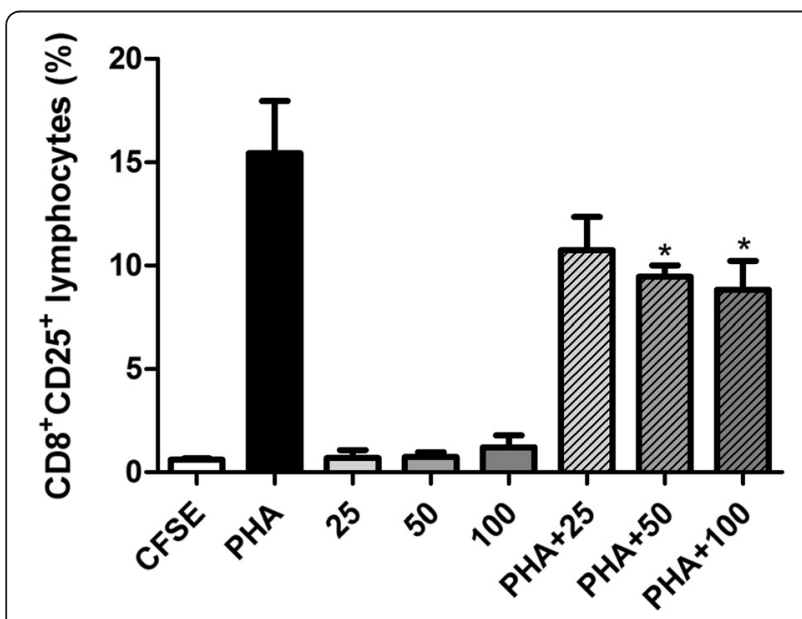

Fig. 3 Percentage of $\mathrm{CD}^{+} \mathrm{T}$ lymphocytes expressing CD25. Peripheral blood mononuclear cells (PBMC; $5 \times 10^{6}$ cells $/ \mathrm{mL}$ ) were labeled with carboxyfluorescein diacetate succinimidyl ester (CFSE; $2.5 \mu \mathrm{M}$ ) and cultured with Tityus serrulatus scorpion venom (TsV; 25 , 50 , and $100 \mu \mathrm{g} / \mathrm{mL}$ ) alone or in combination with phytohemagglutinin (PHA; $2 \mu \mathrm{g} / \mathrm{mL}$ ) for $96 \mathrm{~h}$ at $37^{\circ} \mathrm{C}$, and under $5 \% \mathrm{CO}_{2}$. Then, PBMC were collected, labeled with anti-CD3/PerCP, anti-CD8/PE, and anti-CD25/APC monoclonal antibodies, and further analyzed by flow cytometry. CFSE: CFSE-stained cells cultured in RPMI; PHA: PHA-stimulated cells (positive control); 25, 50, 100: cells incubated with 25, 50, and $100 \mu \mathrm{g} / \mathrm{mL}$ TsV, respectively; PHA + 25, PHA +50, PHA + 100: cells incubated with PHA plus 25, 50 and $100 \mu \mathrm{g} / \mathrm{mL}$ $\mathrm{TsV}$, respectively. Each column represents the mean $\pm \mathrm{SEM}$ of five experiments. ${ }^{*} p<0.05$ vs. PHA release of other cytokines (IL-2, IL-4, IL-10, IL-17, IFN- $\gamma$, and TNF- $\alpha$ ) by non-stimulated and PHAstimulated PBMC (data not shown).

\section{Discussion}

In Brazil, the yellow scorpion T. serrulatus is the most dangerous Buthidae species and the main cause of serious accidents [4]. Its venom ( $\mathrm{TsV})$ contains toxins that act on $\mathrm{K}^{+}$and $\mathrm{Na}^{+}$channels, a property that accounts for great portion of the venom's toxic effects. Several studies have reported that scorpion venoms and toxins, including TsV, elicit macrophage activation [11-13, 15, 19]. TsV and Ts1 bind Toll-like receptors to mediate cytokine and lipid mediator production [14]. Such reports have helped to elucidate how inflammatory mediators are produced after envenomation.

To date, very little is known about the direct effect of scorpion venoms on human lymphocyte functions. As lymphocytes have membrane $\mathrm{K}^{+}$channels and $\mathrm{TsV}$ contains toxins that interact with these channels, we hypothesized that $\mathrm{TsV}$ and its toxins could affect lymphocyte functions mediated by the activity of $\mathrm{K}^{+}$channels, such as PHA-induced cell proliferation [11, 20-22].

Cell stimulation by pathogens in infectious and inflammatory processes and by mitogens induces the expression of activation markers in T, B, and NK cells. PHA, a commonly used mitogen, is a plant lectin that binds to TCR and activates T lymphocytes [23]. In the present study, we examined the expression of very early (CD69), middle-to-late (CD25), and late (HLA-DR) T cell surface activation markers. CD69 expression can be detected within 1 to $2 \mathrm{~h}$ after $\mathrm{T}$ cell stimulation [24]. It can initiate tyrosine kinase and calcium flux activity, and transcription of IL-2 and TNF- $\alpha$ [25]. The expression of CD25 (the $\alpha-$ chain of the IL-2 receptor) and HLA-DR (a human class II major histocompatibility complex antigen) increases progressively after $24 \mathrm{~h}$ of stimulation with PHA [26].

After establishing the TsV concentrations and incubation time with PBMC, we examined whether TsV alters the percentage of $\mathrm{T}$ lymphocytes, and the extent of $\mathrm{CD}^{+}$and $\mathrm{CD}^{+} \mathrm{T}$ cell proliferation. In the presence of $\mathrm{TsV}$, the percentage of $\mathrm{T}$ lymphocytes (data not shown), as well as the percentage of CD3 ${ }^{+} \mathrm{CD}^{+}$and $\mathrm{CD}^{+}{ }^{+} \mathrm{CD}^{+}$lymphocyte subpopulations expressing CD69, CD25, and HLA-DR were similar to the untreated controls. However, maximum expression of some activation markers, especially CD25 and 


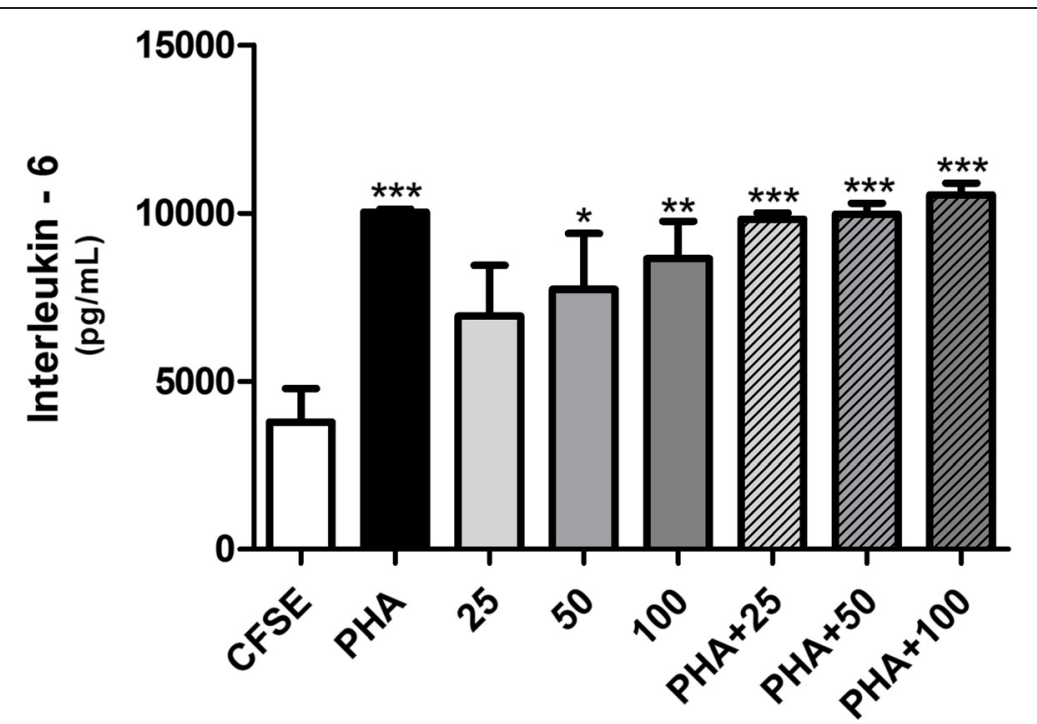

Fig. 4 Interleukin-6 (IL-6) release by PBMC treated with Tityus serrulatus scorpion venom (TsV) for 96 h. Peripheral blood mononuclear cells (PBMC; $5.0 \times 10^{5}$ cells) were labeled with carboxyfluorescein diacetate succinimidyl ester (CFSE; $\left.2.5 \mu \mathrm{M}\right)$ and cultured with TsV $(25,50$, and 100 $\mu \mathrm{g} / \mathrm{mL})$ alone or in combination with phytohemagglutinin (PHA; $2 \mu \mathrm{g} / \mathrm{mL}$ ) for $96 \mathrm{~h}$. The levels of IL-6 in culture supernatants were determined by flow cytometry. CFSE: CFSE-stained cells cultured in RPMI 1640; PHA: PHA-stimulated cells (positive control); 25, 50, 100: cells incubated with 25, 50, and $100 \mu \mathrm{g} / \mathrm{mL}$ TsV, respectively; PHA + 25, PHA + 50, PHA + 100: cells incubated with PHA plus 25, 50, and $100 \mu \mathrm{g} / \mathrm{mL}$ TsV, respectively. Each column represents the mean \pm SEM of five experiments. ${ }^{*} p<0.05,{ }^{* *} p<0.01,{ }^{* * *} p<0.001$ vs. CFSE

HLA-DR, may occur later. It suggests that the PBMC culture periods used $(24 \mathrm{~h}$ and $96 \mathrm{~h})$ were not sufficient to detect significant alterations in the expression level of these markers. To confirm this hypothesis, it is necessary to perform additional experiments using longer culture times. Another possibility is to use higher $\mathrm{TsV}$ concentrations to better evaluate its action on the expression of lymphocyte activation markers.

To assess lymphocyte proliferation, we selected CFSE due to its compatibility with several other fluorochromes, which enabled us to simultaneously evaluate several parameters including the percentage of activated cells and proliferation of distinct populations of activated cells, using multi-color flow cytometry [27]. With the aid of this technique, we found that $\mathrm{TsV}$ at 50 and $100 \mu \mathrm{g} / \mathrm{mL}$ significantly decreased the percentage of $\mathrm{CD}^{+} \mathrm{CD} 25^{+} \mathrm{T}$ cells in PHA-stimulated PBMC (Fig. 3). Considering that ion channels participate in an early stage of cell activation by PHA, it is possible that toxins that exist in $\mathrm{TsV}$ act on ions channels in $\mathrm{CD} 8{ }^{+} \mathrm{CD} 25^{+} \mathrm{T}$ cells and thereby impair the action of PHA on these cells [22]. It is well documented that ion channels play important roles in the activation and proliferation of lymphocytes, as well as in the production of cytokines $[20,28,29]$. Blockage of the $\mathrm{K}^{+}$channel Kv1.3 inhibits mitogen-induced $\mathrm{T}$ cell proliferation, protein synthesis and IL-2 production [20].

Cytokines are produced during the effector phases of innate and acquired immune responses and regulate immune and inflammatory responses $[30,31]$. Besides the knowledge that TsV and its toxins are potent inducers of cytokine and lipid mediator production in vitro and in vivo $[11-15,19]$, little is known about the effect of TsV on the production of cytokines by human PBMC. We measured the levels of various cytokines - IL-2, IL-4, IL-6, IL-10, IL-17, IFN- $\gamma$ and TNF- $\alpha$ - in the supernatant of PBMC cultures after $96 \mathrm{~h}$ of treatment with PHA and/or different concentrations of crude TsV. Compared with untreated cells, $\mathrm{TsV}$ at 50 and $100 \mu \mathrm{g} / \mathrm{mL}$ significantly increased IL-6 release in nonstimulated cells $(p<0.05$ and $p<0.01$, respectively) (Fig. 4). In contrast, TsV did not alter the PHAinduced IL-6 production by PBMC. Our results partially agree with those reported by several in vitro and in vivo studies $[11-15,19]$. TsV fractions stimulate the macrophage production of proinflammatory cytokines such as TNF- $\alpha$, IL-1, and IL-6 [32]. TsV and the toxins Ts1 and Ts6 stimulate the production of NO, IL-6, and TNF- $\alpha$ in J774.1 cells [12]. When inoculated in mice, Ts2 and Ts6 induce the production of the proinflammatory cytokines IL-6, TNF- $\alpha$, IL- $1 \beta$, and IFN- $\gamma$, and the lipid mediators prostaglandin E2 and leukotriene B4 [13]. Several authors have reported that IL- 6 levels are increased after envenomation in humans $[9,33-35]$.

To the best of our knowledge, this is the first study that shows immunomodulatory actions of $\mathrm{TsV}$ on human $\mathrm{T}$ lymphocytes. Taken together, our results suggest that TsV is a potential source of molecules with immunomodulatory effects on these cells, and should stimulate further 
research to elucidate the action mechanisms involved, including the participation of $\mathrm{T}$ lymphocyte ion channels in the phenomena observed.

\section{Conclusions}

$\mathrm{Ts} \mathrm{V}$ is a potential immunomodulator of human $\mathrm{T}$ lymphocyte functions. The results reported herein stimulate further investigations to identify the venom components responsible for the observed effects and to elucidate the molecular mechanisms involved in $\mathrm{Ts} \mathrm{V}$ immunomodulatory action on lymphocytes. These investigations may facilitate the development of new tools to study the pathophysiological mechanisms of envenomation and to discover new treatment alternatives for diseases mediated by the immune system.

\section{Ethics committee approval}

The present study was approved by the Human Research Ethics Committee at FCFRP-USP registered under number CEP/FCFRP 166.

\section{Additional file}

Additional file 1: Representative picture showing forward/side scatter dot-plot of human PBMC treated with TsV. Peripheral blood mononuclear cells (PBMC; $2 \times 10^{6}$ cells $/ \mathrm{mL}$ ) were cultured with Tityus serrulatus scorpion venom $(T s V ; 25,50$, and $100 \mu \mathrm{g} / \mathrm{mL})$, phytohemagglutinin (PHA; $2 \mu \mathrm{g} / \mathrm{mL}$; positive control) for $24 \mathrm{~h}$, at $37^{\circ} \mathrm{C}$, and under $5 \% \mathrm{CO}_{2}$. Untreated PBMC represents the negative control. PBMC were labeled with anti-CD3/FITC and anti-CD8/PE monoclonal antibodies and further analyzed by flow cytometry. The lymphocyte gate was selected and analyzed to calculate the percentage of stained cells. The figure depicts a representative analysis from six independent experiments. The percentages in parentheses refer to CD3+ CD8+ cells (P2 region). (A) Negative control (5.5\%). (B) PHA-stimulated cells (26.1\%). (C) $100 \mu \mathrm{g} / \mathrm{mL}$ of TsV (4.9\%). (D) $50 \mu \mathrm{g} / \mathrm{mL}$ of $\mathrm{TsV}(6.4 \%)$. (E) $25 \mu \mathrm{g} / \mathrm{mL}$ of TsV (8.4\%). (DOCX $204 \mathrm{~kb})$

\section{Competing interest}

The authors declare that there is no conflict of interest.

\begin{abstract}
Authors' contributions
ACM performed the experiments and data analysis. LRA, JCP and SMB collaborated in the experiments and contributed to the conception of this manuscript. FRM performed the flow cytometry assays and contributed to the data analysis. ACM, LRA, SMB, FAC and LSPC wrote and reviewed the manuscript. FAC, LSPC and SVS raised funds for the research. ECA, SVS and LHF contributed to the writing of the manuscript. ECA also supervised the collection and preparation of TSV. LSPC and FAC conceived and coordinated the study, contributed to the interpretation of data and critically discussed the manuscript. All authors read and approved the final manuscript.
\end{abstract}

\section{Acknowledgments}

The authors would like to thank the Nucleus for Research on Animal Toxins (NAP-TOXAN-USP, grant n. 12-125432.1.3), the State of São Paulo Research Foundation (FAPESP, grant n. 2011/23236-4), the Coordination for the Improvement of Higher Education Personnel (CAPES, ACM, JCP and SMB grants) and the National Council for Scientific and Technological Development (CNPq, SMB grant) for their funding of this research. We also thanks to T. M. Casare-Ogasawara for the technical support. Thanks are also due to the Center for the Study of Venoms and Venomous Animals (CEVAP) of UNESP for enabling the publication of this special collection (CNPq process 469660/2014-7).

\section{Author details}

${ }^{1}$ Department of Clinical Analyses, Toxicology and Food Sciences, School of Pharmaceutical Sciences of Ribeirão Preto, University of São Paulo (USP), Avenida do Café, s/n, Ribeirão Preto, SP CEP 14040-903, Brazil. Department of Pharmaceutical Sciences, Federal University of Espírito Santo, Vitória, ES, Brazil. ${ }^{3}$ Department of Physics and Chemistry, School of Pharmaceutical Sciences of Ribeirão Preto, University of São Paulo (USP), Ribeirão Preto, SP, Brazil.

Received: 19 February 2015 Accepted: 5 November 2015

Published online: 11 November 2015

\section{References}

1. Chippaux JP, Goyffon M. Epidemiology of scorpionism: a global appraisal. Acta Trop. 2008;107(2):71-9.

2. Chippaux JP. Epidemiology of envenomations by terrestrial venomous animals in Brazil based on case reporting: from obvious facts to contingencies. J Venom Anim Toxins incl Trop Dis. 2015;21:13. doi:10.1186/ s40409-015-0011-1.

3. Cupo P, Jurca M, Azevedo-Marques MM, Oliveira JSM, Hering SE. Severe scorpion envenomation in Brazil: clinical, laboratory and anatomopathological aspects. Rev Inst Med Trop São Paulo. 1994;36(1):67-76.

4. Lourenço WR. What do we know about some of the most conspicuous scorpion species of the genus Tityus? A historical approach. J Venom Anim Toxins incl Trop Dis. 2015;21:20. doi:10.1186/s40409-015-0016-9.

5. Ministério da Saúde, Secretaria de Vigilância em Saúde. Manual de Controle de Escorpiões. Brasília: MS; 2009. http://bvsms.saude.gov.br/bvs/publicacoes/ manual_controle_escorpioes.pdf. (Accessed 10 Nov 2015).

6. Reckziegel GC, Pinto VL. Scorpionism in Brazil in the years 2000 to 2012. J Venom Anim Toxins incl Trop Dis. 2014;20:46. http:// www.jvat.org/content/20/1/46. (Accessed 10 Nov 2015).

7. Bahloul M, Chabchoub I, Chaari A, Chtara K, Kallel H, Dammak H, et al. Scorpion envenomation among children: clinical manifestations and outcome (analysis of 685 cases). Am J Trop Med Hyg. 2010;83(5):1084-92.

8. Isbister KG, Bawaskar HS. Scorpion envenomation. N Engl J Med. 2014;371(5):457-63.

9. Fukuhara YD, Reis ML, Dellalibera-Joviliano R, Cunha FQ, Donadi EA. Increased plasma levels of IL-1 beta, IL-6, IL-8, IL-10 and TNF-alpha in patients moderately or severely envenomed by Tityus serrulatus scorpion sting. Toxicon. 2003;41(1):49-55.

10. Fialho EM, Maciel MC, Silva AC, Reis AS, Assunção AK, Fortes TS, et al. Immune cells recruitment and activation by Tityus serrulatus scorpion venom. Toxicon. 2011;58(6-7):480-5.

11. Ortiz E, Gurrola GB, Schwartz EF, Possani LD. Scorpion venom components as potential candidates for drug development. Toxicon. 2015;93:125-35.

12. Zoccal KF, Bitencourt CS, Secatto A, Sorgi CA, Bordon KC, Sampaio SV, et al. Tityus serrulatus venom and toxins Ts1, Ts2 and Ts6 induce macrophage activation and production of immune mediators. Toxicon. 2011;57(7-8):1101-8.

13. Zoccal KF, Bitencourt CS, Sorgi CA, Bordon KC, Sampaio SV, Arantes EC, et al. Ts6 and Ts2 from Tityus serrulatus venom induce inflammation by mechanisms dependent on lipid mediators and cytokine production. Toxicon. 2013:61:1-10.

14. Zoccal KF, Bitencourt CS, Paula-Silva FW, Sorgi CA, Bordon KCF, Arantes EC, et al. TLR2, TLR4 and CD14 recognize venom-associated molecular patterns from Tityus serrulatus to induce macrophage-derived inflammatory mediators. PLoS ONE. 2014;9(2):e88174. doi:10.1371/journal.pone.0088174.

15. Zoccal KF, Paula-Silva FW, Bitencourt CS, Sorgi CA, Bordon KC, Arantes EC, et al. PPAR- $\gamma$ activation by Tityus serrulatus venom regulates lipid body formation and lipid mediator production. Toxicon. 2015;93:90-7.

16. Lowe RM, Farrell PM. A portable device for the electrical extraction of scorpion venom. Toxicon. 2011;57(2):244-7.

17. Pucca MB, Amorim FG, Cerni FA, Bordon KC, Cardoso IA, Anjolette FA, et al. Influence of post-starvation extraction time and prey-specific diet in Tityus serrulatus scorpion venom composition and hyaluronidase activity. Toxicon. 2014;90:326-36.

18. Mosmann T. Rapid colorimetric assay for cellular growth and survival: application to proliferation and cytotoxicity assays. J Immunol Methods. 1983;65(1-2):55-63.

19. Petricevich VL. Scorpion venom and the inflammatory response. Mediators Inflamm. 2010; Article ID 903295, 16 pages, 2010. doi:10.1155/2010/903295. 
20. Cahalan MD, Chandy KG. The functional network of ion channels in $T$ lymphocytes. Immunol Rev. 2009;1(1):59-87.

21. Cerni FA, Pucca MB, Peigneur S, Cremonez CM, Bordon KCF, Tytgat J, et al. Electrophysiological characterization of Ts6 and Ts7, $\mathrm{K}^{+}$channel toxins isolated through an improved Tityus serrulatus venom purification procedure. Toxins. 2014;6(3):892-913.

22. DeCoursey TE, Chandy KG, Gupta S, Cahalan MD. Voltage-gated $\mathrm{K}^{+}$channels in human T lymphocytes: a role in mitogenesis? Nature. 1984;307(5950):465-8.

23. Licastro F, Davis LJ, Morini MC. Lectins and superantigens: membrane interactions of these compounds with T-lymphocytes affect immune responses. Int J Biochem. 1993;25(6):845-52.

24. Ziegler SF, Ramsdell F, Alderson MR. The activation antigen CD69. Stem Cells. 1994;12(5):456-65.

25. Rea IM, McNerlan SE, Alexander HD. CD69, CD25, and HLA-DR activation antigen expression on CD3+ lymphocytes and relationship to serum TNFalpha, IFN-gamma, and sIL-2R levels in aging. Exp Gerontol. 1999:34(1):79-93.

26. Reddy M, Eirikis E, Davis C, Davis HM, Prabhakar U. Comparative analysis of lymphocyte activation marker expression and cytokine secretion profile in stimulated human peripheral blood mononuclear cell cultures: an in vitro model to monitor cellular immune function. J Immunol Methods. 2004;293(1-2):127-42.

27. Quah BJ, Warren HS, Parish CR. Monitoring lymphocyte proliferation in vitro and in vivo with the intracellular fluorescent dye carboxyfluorescein diacetate succinimidyl ester. Nat Protoc. 2007;2(9):2049-56.

28. Cahalan MD, Wulff H, Chandy KG. Molecular properties and physiological roles of ion channels in the immune system. J Clin Immunol. 2001:21(4):235-52.

29. Urrego D, Tomczak AP, Zahed F, Stühmer W, Pardo LA. Potassium channels in cell cycle and cell proliferation. Philos Trans R Soc Lond B Biol Sci. 2014;369(1638):20130094. doi:10.1098/rstb.2013.0094.

30. Van der Meide PH, Schellekens H. Cytokines and the immune response. Biotherapy. 1996;8(3-4):243-9.

31. Lacy P, Stow JL. Cytokine release from innate immune cells: association with diverse membrane trafficking pathways. Blood. 2011;118(1):9-18.

32. Petricevich VL, Lebrun I. Immunomodulatory effects of the Tityus serrulatus venom on murine macrophage functions in vitro. Mediators Inflamm. 2005;2005(1):39-49.

33. Sofer S, Gueron M, White RM, Lifshitz M, Apte RN. Interleukin-6 release following scorpion sting in children. Toxicon. 1996;34(3):389-92.

34. Magalhães MM, Pereira ME, Amaral CF, Rezende NA, Campolina D, Bucaretchi F, et al. Serum levels of cytokines in patients envenomed by Tityus serrulatus scorpion sting. Toxicon. 1999;37(8):1155-64.

35. Voronov $\mathrm{E}$, Apte RN, Sofer $\mathrm{S}$. The systemic inflammatory response syndrome related to the release of cytokines following severe envenomation. J Venom Anim Toxins. 1999;5(1):5-33. Available at: http://www.scielo.br/ scielo.php?script=sci_arttext\&pid=S0104-79301999000100002. Accessed 10 Nov 2015.

\section{Submit your next manuscript to BioMed Central and take full advantage of:}

- Convenient online submission

- Thorough peer review

- No space constraints or color figure charges

- Immediate publication on acceptance

- Inclusion in PubMed, CAS, Scopus and Google Scholar

- Research which is freely available for redistribution 